Anna PotyraŁA

Uniwersytet im. Adama Mickiewicza, Poznań

\title{
Polska polityka azylowa. Ujęcie prawno-instytucjonalne
}

B lisko pięcioletnia obecność Polski w Unii Europejskiej oraz zaangaB żowanie w tworzenie europejskich rozwiązań prawnych dotyczących uchodźców i innych osób poszukujących schronienia, skłania do zastanowienia nad kształtem polskiej polityki azylowej. Jej początki sięgają 26 września 1991 roku, gdy Rzeczpospolita Polska przystapiła do Konwencji Genewskiej dotyczącej Statusu Uchodźców z 1951 roku oraz do Protokołu Nowojorskiego dotyczącego Statusu Uchodźców z roku 1967. Przyjęcie zobowiązań wynikających z treści Konwencji i Protokołu nałożyło na polskiego ustawodawcę konieczność znowelizowania ustawy o cudzoziemcach z 29 marca 1963 roku, gdyż polskie prawo wewnętrzne nie regulowało wcześniej kwestii uchodźstwa. Do chwili przyjęcia przez Rzeczpospolitą Polską Konwencji z 1951 roku i Protokołu z roku 1967, polskie prawo wewnętrzne nie znało instytucji statusu uchodźcy. Cudzoziemcy zwracający się o ochronę do władz Rzeczypospolitej mogli skorzystać z prawa azylu (w rozumieniu azylu terytorialnego). Konstytucja Lipcowa z 1952 roku w artykule 75 przewidywała możliwość udzielenia azylu obywatelom innych państw, którzy byli prześladowani za obronę interesów mas pracujących, walkę o postęp społeczny, działalność w obronie pokoju, walkę narodowowyzwoleńczą lub działalność naukową. 18 października 1991 roku znowelizowano ten zapis, przyznając na mocy artykułu 88 obywatelom innych państw oraz bezpaństwowcom prawo korzystania z azylu na zasadach określonych ustawą. We wrześniu 1991 roku dokonano zmiany ustawy o cudzoziemcach. Nowelizacja wprowadziła dwie instytucje, z których mogli korzystać cudzoziemcy poszukujący schronienia na terytorium Polski: azyl terytorialny oraz status uchodźcy (określany mianem azylu politycznego) ${ }^{1}$.

1 Na gruncie polskiej nauki prawa odróżnia się pojęcie azylu od statusu uchodźcy. Azyl traktowany jest przez polskiego ustawodawcę jako instytucja prawa wewnętrz- 


\section{Rozwiązania prawne}

Nowelizacja ustawy z 1963 roku nie zakończyła działań legislacyjnych. Rosnąca liczba cudzoziemców ubiegających się o status uchodźcy, brak szczegółowych uregulowań dotyczących kwestii uchodźstwa oraz niezgodność niektórych zapisów ustawy z 1963 roku z zaleceniami Komitetu Wykonawczego Urzędu Wysokiego Komisarza Narodów Zjednoczonych do Spraw Uchodźców, doprowadziły do przyjęcia nowych rozwiązań prawnych. 25 czerwca 1997 roku uchwalono ustawę o cudzoziemcach, w której kompleksowo uregulowano postępowanie w sprawie nadania, odmowy nadania lub cofnięcia statusu uchodźcy. Uwzględniając wytyczne Urzędu Wysokiego Komisarza NZ do Spraw Uchodźców (UNHCR) przewidziano powołanie Rady do Spraw Uchodźców - instancji odwoławczej od decyzji podjętej przez Ministra Spraw Wewnętrznych i Administracji w sprawie odmowy wszczęcia postępowania, odmowy przyznania statusu uchodźcy lub w sprawie cofnięcia statusu. Utrzymano jednocześnie możliwość przyznania azylu cudzoziemcom, którzy nie spełniają wymagań stawianych przez Konwencję Genewską, lecz gdy jest to niezbędne dla zapewnienia im ochrony i gdy przemawia za tym ważny interes Rzeczypospolitej Polskiej.

W związku z koniecznością dostosowania polskiego ustawodawstwa do wymogów stawianych przez Unię Europejską, w kwietniu 2001 roku ustawa o cudzoziemcach została znowelizowana. Najważniejszą zmianą było wprowadzenie, obok azylu terytorialnego i statusu uchodźcy, tzw. ochrony tymczasowej. Ta forma ochrony przysługiwać miała cudzoziemcom opuszczającym masowo państwo pochodzenia ,z powodu obcej inwazji, wojny, wojny domowej, konfliktów etnicznych lub rażących naruszeń praw człowieka", którzy w ramach pomocy tymczasowej otrzymywali zakwaterowanie, wyżywienie i opiekę medyczną, do chwili, gdy zaistnie-

nego, a rozumiany jako ochrona, której przyznanie, odmowa przyznania lub cofnięcie zależne jest wyłącznie od decyzji władz danego państwa. Status uchodźcy zdefiniować można natomiast jako ochronę przyznawaną przez władze państwa, które w swoich decyzjach związane są zobowiązaniami wynikającymi z przyjętych dokumentów międzynarodowych. Decyzje o udzieleniu, odmowie przyznania lub cofnięciu statusu uchodźcy wydawane być muszą w oparciu o postanowienia Konwencji dotyczącej Statusu Uchodźców i Protokołu Dodatkowego.

2 Artykuł 51a Ustawy z dnia 25 czerwca 1997 r. o cudzoziemcach, tekst jednolity - Dz. U. Nr 126, poz. 1400 z późn. zm. 
je możliwość ich powrotu do państw pochodzenia. Utrzymując większość rozwiązań wprowadzonych w roku 1997, uniemożliwiono staranie się o status uchodźcy osobom powołującym się na obawę przed prześladowaniem występującym jedynie na określonej części terytorium państwa pochodzenia, jeśli istniała możliwość uzyskania schronienia w innej części terytorium tego państwa.

13 czerwca 2003 roku w miejsce dotychczas obowiązującej ustawy o cudzoziemcach uchwalono Ustawę o cudzoziemcach oraz Ustawę o udzielaniu cudzoziemcom ochrony na terytorium Rzeczypospolitej Polskiej, w której uregulowano kwestie dotyczące azylu terytorialnego, statusu uchodźcy, pobytu tolerowanego oraz ochrony czasowej. Postanowienia obu ustaw weszły w życie 1 września 2003 roku, a uzupełnione zostały rozporządzeniami Ministra Spraw Wewnętrznych i Administracji, Ministra Pracy i Polityki Społecznej, Ministra Spraw Zagranicznych oraz Ministra Zdrowia. 12 kwietnia 2005 roku obie ustawy zostały znowelizowane. Ostatnią nowelizację przyjęto 18 marca 2008 roku. Jej celem było dalsze dostosowanie polskiego prawa do rozwiązań Unii Europejskiej w zakresie ochrony cudzoziemców.

Najważniejsze zmiany wprowadzone na mocy nowelizacji z 2005 i 2008 roku dotyczyły postępowania o przyznanie statusu uchodźcy. Zgodnie z artykułem 13.1 ustawy o udzielaniu cudzoziemcom ochrony każdy cudzoziemiec, który opuścił państwo pochodzenia z uwagi na uzasadnioną obawę przed prześladowaniem z powodu rasy, religii, narodowości, przekonań politycznych lub przynależności do określonej grupy społecznej, i który nie chce lub nie może korzystać z ochrony własnego państwa, może ubiegać się o ochronę w RP. Uznano, że prześladowanie może być efektem działania lub zaniechania, stanowiącego naruszenie praw człowieka i polegać między innymi na:

- użyciu przemocy fizycznej lub psychicznej, w tym przemocy seksualnej;

- zastosowaniu środków prawnych, administracyjnych, policyjnych lub sądowych w sposób dyskryminujący lub o charakterze dyskryminującym;

- wszczęciu lub prowadzeniu postępowania karnego lub ukaraniu, w sposób, który ma charakter nieproporcjonalny lub dyskryminujący;

- braku prawa odwołania się do sądu od kary o charakterze nieproporcjonalnym lub dyskryminującym;

- wszczęciu lub prowadzeniu postępowania karnego lub ukaraniu z powodu odmowy odbycia służby wojskowej podczas konfliktu; 
- czynach przeciw osobom z uwagi na ich płeć lub małoletniość ${ }^{3}$.

Niezwykle pozytywnie ocenić należy zmiany wprowadzone na mocy nowelizacji z 2005 roku, zgodnie z którymi o status uchodźcy można ubiegać się niezależnie od tego, czy autorem prześladowań są władze państwowe czy tzw. aktorzy niepaństwowi, kontrolujący przynajmniej część terytorium państwa ${ }^{4}$. Często bowiem zdarzają się przypadki, że organy państwa nie są w stanie zagwarantować ochrony swym obywatelom, gdyż tracą kontrolę nad częścią terytorium państwa na rzecz grup powstańczych. Sytuacje takie obserwować można w każdym państwie targanym wojną domową, od Gruzji, przez Sri Lankę, Myanmar po Sudan czy do niedawna państwa Ameryki Środkowej.

Z wnioskiem o przyznanie statusu uchodźcy występuje zainteresowany cudzoziemiec, wskazując dane osobowe swoje, towarzyszących mu małoletnich dzieci oraz współmałżonka, państwo pochodzenia, a także istotne zdarzenia będące przyczyną ubiegania się o status. Zgodnie z artykułem 28 ustawy, wniosek należy złożyć do Szefa Urzędu do spraw Cudzoziemców za pośrednictwem komendanta oddziału lub placówki Straży Granicznej (o czym szerzej w dalszej części niniejszego artykułu). Wniosek o przyznanie statusu uchodźcy może złożyć nie tylko cudzoziemiec przekraczający granicę RP lub przebywający legalnie na terytorium Polski, ale również cudzoziemiec oczekujący w ośrodku strzeżonym lub areszcie na wydalenie $\mathrm{z}$ terytorium $\mathrm{RP}$, lub przebywający $\mathrm{w}$ areszcie śledczym czy zakładzie karnym (sytuacja ta dotyczy na przykład cudzoziemca, w odniesieniu do którego zachodzi uzasadniona obawa, że nie podporządkuje się on zasadom obowiązującym w ośrodku strzeżonym). Rozwiązanie takie jest zgodne z postanowieniami dokumentów międzynarodowych, zgodnie z którymi nawet osoba nielegalnie przebywająca na terytorium państwa może ubiegać się o ochronę, jeśli w państwie pochodzenia zetknęła się z prześladowaniem lub ryzykiem prześladowania. W przypadku wszczęcia postępowania w sprawie, wstrzymaniu ulega wykonanie decyzji w sprawie wydalenia cudzoziemca $z$ terytorium RP lub wykonanie decyzji w sprawie zobowiązania cudzoziemca do opuszczenia terytorium Polski ${ }^{5}$.

3 Por. Artykuł 13.4 Ustawy z dnia 13 czerwca 2003 roku o udzielaniu cudzoziemcom ochrony na terytorium Rzeczypospolitej Polskiej, z późn. zm., Dz. U. 2008, Nr 70, poz. 416.

4 Por. Artykuł 16.1 Ustawy z dnia 13 czerwca 2003 roku o udzielaniu cudzoziemcom ochrony na terytorium Rzeczypospolitej Polskiej, op. cit.

5 Por. Artykuł 33.1 Ustawy z dnia 13 czerwca 2003 roku o udzielaniu cudzoziemcom ochrony na terytorium Rzeczypospolitej Polskiej, op. cit. 
W odróżnieniu od wcześniejszych uregulowań prawnych, ustawa o udzielaniu cudzoziemcom ochrony z 2003 roku nie wskazuje terminów, w których musi nastąpić złożenie wniosku o nadanie statusu uchodźcy. Dzięki temu cudzoziemcy przebywający w Polsce legalnie, którzy w czasie pobytu otrzymali informację o zaistnieniu w państwie pochodzenia okoliczności uzasadniających nadanie statusu, mogą w każdej chwili ubiegać się o status. Takie rozwiązanie jest zgodne z Konwencją Genewską z 1951 roku, w myśl której status uchodźcy przysługuje nie tylko ofiarom prześladowań, ale również osobom żywiącym uzasadnioną obawę przed prześladowaniem, powodującą niemożność powrotu do państwa pochodzenia.

Z uwagi na fakt, iż Konwencja Genewska z 1951 roku oraz Protokół Nowojorski z roku 1967 nie regulują kwestii proceduralnych, w ustawie o udzielaniu cudzoziemcom ochrony na terytorium RP odniesiono się do tych zagadnień. Wszczęcie postępowania w sprawie powoduje konieczność ustalenia między innymi: tożsamości cudzoziemca; państwa pochodzenia cudzoziemca; trasy przejazdu do granicy Rzeczypospolitej Polskiej i miejsca przekroczenia granicy; a także faktu ubiegania się o status uchodźcy w innym państwie. W toku postępowania cudzoziemiec jest więc zobowiązany do złożenia zeznań i wyjaśnień oraz do udostępnienia wszelkich posiadanych dowodów potwierdzających okoliczności uzasadniające nadanie statusu. Zgodnie z artykułem 55.1-2 ustawy, cudzoziemiec, który złożył wniosek o przyznanie statusu uchodźcy otrzymuje tymczasowe zaświadczenie tożsamości na okres 30 dni z możliwością przedłużenia do czasu zakończenia postępowania w sprawie. W zaświadczeniu wskazuje się imię i nazwisko cudzoziemca, datę urodzenia lub wiek, miejsce i państwo urodzenia, obywatelstwo, a także imiona i nazwiska małoletnich dzieci towarzyszących cudzoziemcowi. Ponadto, na okres postępowania $\mathrm{w}$ sprawie i przez 2 miesiące od doręczenia decyzji ostatecznej lub przez 14 dni od doręczenia decyzji w sprawie umorzenia postępowania, cudzoziemcowi przyznaje się pomoc socjalną i opiekę medyczną. Pomoc socjalna realizowana jest w ośrodku dla uchodźców (patrz: tabela 1) i obejmuje wyżywienie, zakwaterowanie, finansowanie przejazdów środkami transportu publicznego (w celu wzięcia udziału w postępowaniu o przyznanie statusu uchodźcy, stawienia się na badania lekarskie), a także stałą pomoc pieniężną na zakup środków higieny osobistej i pokrycie drobnych wydatków osobistych (dla cudzoziemców wykonujących prace porządkowe na rzecz ośrodka lub tłumaczenia ułatwiające porozumiewanie się między pracownikami ośrodka a cudzoziemcami, pomoc może być 
podwyższona) ${ }^{6}$. Cudzoziemiec przebywający w ośrodku ma również prawo nauki języka polskiego oraz prawo pobierania nauki w publicznych szkołach podstawowych, gimnazjalnych i ponadgimnazjalnych. W przypadku dzieci korzystających z prawa do nauki zapewniane są pomoce dydaktyczne oraz pokrywane koszty wynikające z opłat za naukę. Cudzoziemiec przebywający w ośrodku dla uchodźców ma również prawo do podtrzymywania tradycji i zwyczajów narodowych, odbywania praktyk religijnych, a także do swobodnego poruszania się po terenie ośrodka. Dodatkowo, na mocy nowelizacji z 22 kwietnia 2005 roku, przyznano osobom ubiegającym się o status (których procedura uchodźcza przedłuża się o ponad rok nie z ich winy) prawo do ubiegania się o zezwolenie na wykonywanie pracy.

Tabela 1

Ośrodki dla uchodźców na terytorium RP (stan na grudzień 2008 roku)

\begin{tabular}{||l|l|l||}
\hline \multicolumn{1}{|c|}{ Województwo } & \multicolumn{1}{|c||}{ Miasto } & \multicolumn{1}{c||}{ Nazwa ośrodka } \\
\hline Kujawsko-Pomorskie & Grupa koło Grudziądza & Grupa \\
\hline Lubelskie & $\begin{array}{l}\text { Lublin } \\
\text { Lubycza Królewska } \\
\text { Luków } \\
\text { Niemce } \\
\text { Zalesie }\end{array}$ & $\begin{array}{l}\text { Hotel Pumis } \\
\text { Lubycza Królewska } \\
\text { Hotel Polonia } \\
\text { Bezwola, Leonów } \\
\text { Kolonia Horbów }\end{array}$ \\
\hline Mazowieckie & $\begin{array}{l}\text { Dędak } \\
\text { Linin } \\
\text { Pruszków } \\
\text { Puste Łąki } \\
\text { Radom } \\
\text { Warszawa } \\
\text { Zakroczyn }\end{array}$ & $\begin{array}{l}\text { Ośrodek UdSC } \\
\text { Ośrodek Linin } \\
\text { Moszna } \\
\text { Ośrodek Puste Ląki } \\
\text { Hotel Ustronie } \\
\text { Zajazd 'Lipsk'; Dom Dziecka nr 9; Siekierki } \\
\text { Smoszewo }\end{array}$ \\
\hline Podlaskie & $\begin{array}{l}\text { Białystok } \\
\text { Czerwony Bór } \\
\text { Lomża }\end{array}$ & $\begin{array}{l}\text { Hotel IGA; Zajazd Budowlani } \\
\text { Ośrodek UdSC } \\
\text { Zajazd 'Zacisze' }\end{array}$ \\
\hline Śląskie & $\begin{array}{l}\text { Bytom } \\
\text { Katowice }\end{array}$ & $\begin{array}{l}\text { Bytom } \\
\text { Ośrodek }\end{array}$ \\
\hline \hline
\end{tabular}

Źródło: Opracowanie własne na podstawie danych Urzędu do spraw Cudzoziemców, Warszawa grudzień 2008.

6 Paragraf 3.1 i 4.1-2 Rozporzadzenia Ministra Spraw Wewnętrznych i Administracji z dnia 14 sierpnia 2003 roku w sprawie wysokości pomocy dla cudzoziemców ubiegajacych sięo nadanie statusu uchodźcy, Dz. U. Nr 146, poz. 1428. Niniejsze rozporządzenie weszło w życie 1 września 2003 roku. Patrz też: Artykuł 71.1 Ustawy z dnia 13 czerwca 2003 roku o udzielaniu cudzoziemcom ochrony na terytorium Rzeczypospolitej Polskiej, op. cit. 
W ośrodku zakazane jest między innymi posiadanie broni lub amunicji, środków odurzających i substancji psychotropowych, spożywanie napojów alkoholowych ${ }^{7}$. Pobyt $\mathrm{w}$ ośrodku ulega zakończeniu następnego dnia po ustaniu świadczenia pomocy socjalnej i opieki medycznej.

W sytuacji, gdy pobyt w ośrodku dla uchodźców jest niewskazany ze względu na stan zdrowia cudzoziemca (stwierdzony orzeczeniem lekarskim), konieczność zapewnienia mu bezpieczeństwa (o status uchodźcy w Polsce ubiegają się osoby należące do różnych grup etnicznych, będące wyznawcami różnych religii, co często powoduje konflikty), lub z uwagi na konieczność utrzymania więzi rodzinnych, cudzoziemcowi przyznaje się świadczenie pieniężne na pokrycie kosztów pobytu na terytorium Polski, z wyjątkiem kosztów opieki medycznej (ta przyznawana jest na ogólnych zasadach). Wypłata świadczeń pieniężnych dla takich osób następuje $\mathrm{z}$ góry do 15 dnia danego miesiąca $\mathrm{w}$ ośrodku położonym najbliżej miejsca zamieszkania cudzoziemca.

Wydanie decyzji o nadaniu lub odmowie nadania statusu uchodźcy poprzedza prośba skierowana „do Szefa Agencji Bezpieczeństwa Wewnętrznego, a w razie potrzeby do innych organów" o przekazanie informacji czy wobec cudzoziemca istnieją poważne podstawy, by sądzić, że popełnił, podżegał lub uczestniczył w popełnieniu zbrodni przeciw pokojowi, zbrodni wojennej, przeciw ludzkości, czynów sprzecznych z celami i zasadami Narodów Zjednoczonych lub zbrodni o charakterze niepolitycznym oraz czy pobyt cudzoziemca na terytorium RP stanowi zagrożenie dla obronności i bezpieczeństwa państwa. Jeśli w terminie 30 dni wskazane organy nie przekażą informacji, uznaje się, że wymóg ich uzyskania został spełniony, chyba że organ zobowiązany do udzielenia informacji zawiadomi o przedłużeniu tego terminu do 3 miesięcy ${ }^{8}$. Uzyskanie takich informacji jest istotne, gdyż status uchodźcy nie może być udzielony osobie, w stosunku do której istnieją podejrzenia, że: dokonała ona zbrodni przeciwko pokojowi, zbrodni wojennej lub zbrodni przeciw ludzkości; dokonała poważnej zbrodni o charakterze niepolitycznym; jest winną czynów sprzecznych z celami i zasadami Karty Narodów

7 Paragraf 10.1 i 11 Rozporzqdzenia Ministra Spraw Wewnętrznych i Administracji z dnia 12 sierpnia 2003 roku w sprawie regulaminu pobytu w ośrodku dla cudzoziemców ubiegajacych sięo nadanie statusu uchodźcy, Dz. U. Nr 146, poz. 1425.

${ }^{8}$ Artykuł 45.3-4 Ustawy z dnia 13 czerwca 2003 roku o udzielaniu cudzoziemcom ochrony na terytorium Rzeczypospolitej Polskiej, op. cit. 
Zjednoczonych ${ }^{9}$. O ile zrozumiała jest chęć wyeliminowania sytuacji, w których status uchodźcy zostałby przyznany osobom nie zasługującym na międzynarodową ochronę, o tyle uzyskanie informacji wskazujących, iż pobyt cudzoziemca na terytorium Polski stanowić może zagrożenie dla obronności i bezpieczeństwa państwa może skutkować odmową przyznania statusu uchodźcy jedynie przy zachowaniu postanowień artykułu 32 Konwencji Genewskiej. Zgodnie z tym zapisem powołując się na konieczność zapewnienia bezpieczeństwa lub porządku publicznego władze państwa moga podjąc decyzję o wydaleniu uchodźcy, ale przy zapewnieniu cudzoziemcowi rozsądnego czasu na staranie się o legalne przyjęcie w innym państwie.

Jeśli w toku postępowania potwierdzone zostaną okoliczności wskazane przez cudzoziemca we wniosku, a uzasadniające ubieganie się o status, wówczas podejmowana jest decyzja o nadaniu statusu uchodźcy. W przeciwnym przypadku $\mathrm{w}$ sprawie wydana zostanie decyzja negatywna. Wówczas, za wyjątkiem okoliczności wskazanych w ustawie, w ciagu 30 dni od doręczenia decyzji negatywnej, cudzoziemiec zobowiązany jest do opuszczenia terytorium RP. Ustawa o udzielaniu cudzoziemcom ochrony na terytorium Rzeczypospolitej Polskiej w artykule 19.1-3 określa sytuacje, w których dochodzi do odmowy nadania statusu uchodźcy. Decyzja odmowna podjęta zostanie, gdy nie istnieje uzasadniona obawa przed prześladowaniem, lub gdy zachodzą okoliczności wyłączające możliwość przyznania statusu uchodźcy (osoba korzysta z ochrony lub pomocy organów lub agencji Organizacji Narodów Zjednoczonych innych niż Urząd Wysokiego Komisarza NZ do spraw Uchodźców; istnieje podejrzenie, że wnioskodawca popełnił zbrodnię przeciw pokojowi, wojenną, przeciw ludzkości lub działał sprzecznie z zasadami i celami Karty Narodów Zjednoczonych; lub popełnił zbrodnię o charakterze niepolitycznym przed wystapieniem o status uchodźcy). Status uchodźcy nie zostanie przyznany, gdy cudzoziemiec jest podejrzany o podżeganie do wymienionych wyżej czynów lub o uczestnictwo w ich popełnieniu w inny sposób. Uwzględniając praktykę azylową w Polsce i w innych państwach członkowskich Unii Europejskiej, uznano, że statusu uchodźcy nie może otrzymać osoba, która celowo wytworzyła okoliczności powodujące zaistnienie obawy przed prześladowaniem ${ }^{10}$. Bezcelowe wydaje się natomiast ujęcie w usta-

9 Artykuł 1F Konwencji dotyczqcej statusu uchodźców, Genewa 1951, Dz. U. 1991, $\mathrm{Nr}$ 119, poz. 515.

10 Artykuł 19.3 Ustawy z dnia 13 czerwca 2003 roku o udzielaniu cudzoziemcom ochrony na terytorium Rzeczypospolitej Polskiej, op. cit. 
wie jako okoliczność powodującą odmowę przyznania statusu uchodźcy faktu posiadania praw związanych z posiadaniem obywatelstwa polskiego. Taką sytuację należałoby uznać raczej za powodującą bezzasadność wniosku.

W ustawie określono także okoliczności uzasadniające umorzenie postępowania. Dzieje się tak w przypadku niedopuszczalności wniosku o przyznanie statusu uchodźcy, w szczególności, gdy osoba posiada status uchodźcy przyznany w innym państwie, lub gdy po otrzymaniu decyzji negatywnej złożyła kolejny wniosek oparty o te same okoliczności. Umorzenie postępowania nastąpi również w sytuacji, gdy wnioskodawca:

- wycofa wniosek o przyznanie statusu uchodźcy,

- opuścił ośrodek na okres dłuższy niż 7 dni bez usprawiedliwionej przyczyny;

- opuścił bez zgody Szefa Urzędu do spraw Cudzoziemców miejsce pobytu, lub nie zgłosił się do właściwych, wskazanych przez Szefa Urzędu organów;

- opuścił terytorium RP;

- nie stawił się na przesłuchanie i nie wskaże w ciągu 7 dni, iż było to spowodowane okolicznościami, za które nie ponosi odpowiedzialności ${ }^{11}$.

Decyzja o umorzeniu postępowania podejmowana jest również w sytuacji przekazania wnioskodawcy do innego państwa członkowskiego Unii Europejskiej w celu prowadzenia postępowania w tym państwie. Takie unormowanie przyjęto w związku z koniecznością dostosowania polskiego prawa do wymogów stawianych przez prawo europejskie w zakresie ochrony cudzoziemców. 18 lutego 2003 roku Rada przyjęła bowiem rozporządzenie Dublin II w sprawie państwa odpowiedzialnego za rozpatrzenie wniosku o nadanie statusu uchodźcy. Zgodnie z rozporządzeniem państwo członkowskie nie jest zobowiązane do rozpatrzenia wniosku o nadanie statusu uchodźcy jeśli: w innym kraju UE przebywają członkowie rodziny wnioskodawcy; drugie państwo członkowskie wydało cudzoziemcowi wizę lub pozwolenie na pobyt; w innym państwie członkowskim nastąpiło nielegalne przekroczenie granicy ${ }^{12}$. Tym samym, na pierwszym

11 Por. Artykuł 42.1 Ustawy z dnia 13 czerwca 2003 roku o udzielaniu cudzoziemcom ochrony na terytorium Rzeczypospolitej Polskiej, op. cit.

12 Patrz: Rozporzqdzenie 343/2003 w sprawie państwa odpowiedzialnego za rozpatrzenie wniosku o przyznanie statusu uchodźcy, 18.02.2003. Szerzej: A. Potyrała, B. Przybylska-Maszner, Leksykon integracji europejskiej w Obszarze 'Sprawiedliwość, Wolność, Bezpieczeństwo', Poznań 2008, s. 107. 
etapie postępowania Urząd do spraw Cudzoziemców weryfikuje czy inne państwo należące do UE nie jest odpowiedzialne za rozpatrzenie wniosku o nadanie statusu uchodźcy.

Obok statusu uchodźcy, ustawa o udzielaniu cudzoziemcom ochrony z 13 czerwca 2003 roku przewiduje możliwość objęcia cudzoziemca innymi formami ochrony. Jedną z nich jest ochrona uzupełniająca, przyznana osobie, która nie spełnia warunków do nadania statusu uchodźcy w przypadku, gdy powrót do państwa pochodzenia może narazić tę osobę „na rzeczywiste ryzyko doznania poważnej krzywdy przez:

- orzeczenie kary śmierci lub wykonanie egzekucji;

- tortury, nieludzkie lub poniżające traktowanie albo karanie;

- poważne i zindywidualizowane zagrożenie dla życia lub zdrowia wynikające z powszechnego stosowania przemocy wobec ludności cywilnej w sytuacji międzynarodowego lub wewnętrznego konfliktu zbrojnego"13.

$\mathrm{Na}$ wniosek cudzoziemca, jeśli jest to niezbędne dla zapewnienia cudzoziemcowi ochrony i gdy przemawia za tym ważny interes państwa, można udzielić ochrony w postaci azylu. Przyjmuje on postać instytucji prawa wewnętrznego, co oznacza, że ochrona obowiązuje wyłącznie na terytorium RP. Azyl zostanie cofnięty, gdy ustały przyczyny, dla których przyznano tę formę ochrony, lub gdy cudzoziemiec korzystający z azylu prowadzi działalność przeciw obronności lub bezpieczeństwu Polski lub porządkowi publicznemu. Decyzji o pozbawieniu azylu towarzyszy decyzja o wydaleniu cudzoziemca ${ }^{14}$.

Istotne znaczenie dla ochrony osób poszukujących schronienia ma zgoda na tzw. pobyt tolerowany. W przypadku, gdy cudzoziemiec nie otrzymał statusu uchodźcy lub azylu, lecz jego wydalenie z terytorium Rzeczypospolitej Polskiej wiązałoby się z zagrożeniem prawa do życia, wolności i bezpieczeństwa osobistego; z ryzykiem poddania takiej osoby torturom lub nieludzkiemu czy poniżającemu traktowaniu lub karaniu; ze zmuszeniem tej osoby do pracy; z pozbawieniem prawa do rzetelnego procesu sądowego lub z ukaraniem bez podstawy prawnej; lub gdy wydalenie naruszałoby prawo do życia rodzinnego bądź prawa dziecka, wówczas osobie takiej wydaje się zgodę na pobyt tolerowany. Zgoda na pobyt

13 Artykuł 15 Ustawy z dnia 13 czerwca 2003 roku o udzielaniu cudzoziemcom ochrony na terytorium Rzeczypospolitej Polskiej, op. cit.

14 Artykuł 91.2 Ustawy z dnia 13 czerwca 2003 roku o udzielaniu cudzoziemcom ochrony na terytorium Rzeczypospolitej Polskiej, op. cit. 
tolerowany zostanie wydana również, gdy wydalenie jest niewykonalne z przyczyn niezależnych od organu wykonującego decyzję o wydaleniu lub z przyczyn niezależnych od cudzoziemca. Uwagę zwraca przede wszystkim fakt, iż właściwy organ jest zobowiązany wydać zgodę na pobyt tolerowany w przypadku spełnienia jednego z powyższych warunków - nie wprowadzono elementu uznaniowości w wydawaniu zgody na pobyt tolerowany. Przyjęcie takich rozwiązań było niezbędne z uwagi na konieczność przestrzegania wskazanej w Konwencji Genewskiej dotyczącej statusu uchodźców z 1951 roku zasady non-refoulement. W myśl regulacji międzynarodowych Państwa - Strony Konwencji Genewskiej i/lub Protokołu Nowojorskiego zobowiązały się nie wydalać i nie zawracać uchodźcy do granicy terytorium, na którym jego życiu lub wolności zagrażałoby niebezpieczeństwo. Zasada ta dotyczy zarówno osób z ustalonym statusem, jak i tych, które złożyły wniosek o nadanie statusu i oczekują na decyzję $^{15}$. Zakaz wydalania i zawracania odnosi się także do osób, które nielegalnie przekroczyły granicę, pod warunkiem, że natychmiast zgłoszą się do właściwych władz i przedstawią ważny powód nielegalnego przyjazdu lub pobytu. Zgodnie z zapisami Konwencji Genewskiej z 1951 roku stosowanie zasady non-refoulement można zawiesić w przypadku osób stanowiących zagrożenie dla bezpieczeństwa państwa. W myśl polskiej ustawy każdy cudzoziemiec, którego wydalenie wiązałoby się z wymienionymi wcześniej konsekwencjami otrzyma zgodę na pobyt tolerowany (a więc również ten, który może stanowić zagrożenie bezpieczeństwa RP). Nie oznacza to jednak, że polski ustawodawca przyznał zasadzie non-refoulement charakter bezwzględny. Zgodnie z artykułem 102.1 punkt 4 omawianej ustawy, zgoda na pobyt tolerowany może zostać cofnięta, gdy dalsze jej obowiązywanie mogłoby spowodować poważne zagrożenie dla bezpieczeństwa i obronności państwa lub dla porządku publicznego.

15 Wytyczne UNHCR dotyczace zatrzymania osób starajacych się o azyl, wyd. przez Biuro Łącznikowe UNHCR (b.m.w.), s. 1. Za taką interpretacją zasady non-refoulement opowiedzieli się również eksperci z dziedziny ochrony uchodźców podczas konferencji odbywającej się w Cambridge w dniach 9-10.07.2001. Ich zdaniem zasada non-refoulement odnosi się zarówno do osób z ustalonym statusem uchodźcy, jak i do tych, których wniosek o nadanie statusu jest dopiero rozpatrywany. Szerzej: Cambridge Roundtable 9-10.07.2001, Global Consultations on International Protection, Geneva 2001. Co więcej, niektórzy eksperci proponują uznanie zasady non-refoulement za normę międzynarodowego prawa zwyczajowego, wskazując, że mamy do czynienia ze spójną, regularną i powszechną praktyką przestrzegania omawianej zasady oraz z przekonaniem o zgodności tej praktyki z obowiązującym prawem międzynarodowym. 
Osobie, której udzielono zgody na pobyt tolerowany, przysługują prawa cudzoziemca korzystającego z zezwolenia na zamieszkanie na terytorium RP na czas określony, między innymi prawo do pracy, prawo do rejestracji w Urzędzie Pracy w charakterze bezrobotnego (co gwarantuje możliwość korzystania z ubezpieczenia zdrowotnego), prawo do renty socjalnej, a także do świadczeń rodzinnych. Istotną zmianę do statusu prawnego osób korzystających ze zgody na pobyt tolerowany przyniosła nowelizacja z 12 kwietnia 2005 roku. Na jej podstawie osoba objęta zgodą na pobyt tolerowany może wystąpić o wydanie polskiego dokumentu podróży w sytuacji, gdy utraciły własny paszport lub gdy minął okres jego ważności. W sytuacji, gdy cudzoziemiec zwróci się dobrowolnie o ochronę do władz państwa pochodzenia lub gdy opuści terytorium Rzeczypospolitej Polskiej, wówczas podjęta zostanie decyzja o cofnięciu zgody na pobyt tolerowany. Podobnie w przypadku, gdy ustanie przyczyna, dla której zgody udzielono. $\mathrm{Z}$ mocy prawa zgoda na pobyt tolerowany wygasa, natomiast gdy cudzoziemiec otrzyma status uchodźcy, obywatelstwo polskie, zezwolenie na osiedlenie się lub gdy cudzoziemiec pisemnie zrzeknie się prawa do korzystania ze zgody na pobyt tolerowany.

W przypadkach masowego napływu cudzoziemców na terytorium Rzeczypospolitej Polskiej w związku z obcą inwazją, wybuchem wojny, wojną domową, konfliktami etnicznymi lub w związku z rażącymi naruszeniami praw człowieka, władze polskie mogą udzielić takim osobom ochrony czasowej ${ }^{16}$. Zgodnie z postanowieniami artykułu 107.1 ustawy, ochrony czasowej udziela się na podstawie i w granicach określonych w decyzji Rady UE z 25 września 1995 roku. Dokument odnosi się do osób, które uzyskały pozwolenie na tymczasowy pobyt na terytorium państw członkowskich Unii. Ochroną mogą być objęte osoby: przetrzymywane w obozach dla jeńców wojennych lub obozach internowania; których życie lub zdrowie jest zagrożone w państwie pochodzenia; które narażone są na przemoc seksualną na terytorium, na którym przebywały; oraz osoby pochodzące $z$ rejonów objętych działaniami zbrojnymi i nie mogące na te tereny powrócić z uwagi na naruszania praw człowieka na tych obszarach ${ }^{17}$.

16 Artykuł 106.1 Ustawy z dnia 13 czerwca 2003 roku o udzielaniu cudzoziemcom ochrony na terytorium Rzeczypospolitej Polskiej, op. cit.

17 Paragraf 1(a) Rezolucji dotyczqcej ponoszenia wspólnej odpowiedzialności w sytuacji przyjęcia i tymczasowego pobytu osób przesiedlonych z 25 września 1995 roku (Resolution on burden - sharing with regard to the admission and residence of displaced persons on a temporary basis, September 25, 1995), „Official Journal” C262, 7.10.1995. 
Udzielenie ochrony czasowej gwarantuje natychmiastowe bezpieczeństwo i możliwość legalnego pobytu nawet tym osobom, które nie są uchodźcami w rozumieniu Konwencji z 1951 roku i Protokołu Nowojorskiego. Cudzoziemiec objęty ochroną czasową w Polsce korzysta z opieki medycznej oraz z pomocy w formie zakwaterowania i wyżywienia, może również wykonywać pracę lub prowadzić działalność gospodarczą na zasadach określonych w ustawie z listopada 1999 roku. Obejmując cudzoziemców ochroną czasową unika się jednak konieczności rozpatrywania indywidualnych spraw i przyznawania statusu uchodźcy poszczególnym osobom. Ponadto, cudzoziemcy muszą się liczyć z możliwością odesłania do państw pochodzenia w momencie, gdy państwo takie uznane zostanie za kraj bezpieczny - państwo, w którym nie ma ryzyka prześladowań ${ }^{18}$. Formalnie, w myśl ustawy, ochrona czasowa obowiązuje do chwili, gdy możliwy będzie powrót, jednak nie dłużej niż 12 miesięcy. W sytuacji, gdy po upływie tego czasu nie ustaną przyczyny do bezpiecznego powrotu, ochronę czasową przedłuża się o 6 miesięcy. Takie przedłużenie może nastąpić jednak tylko dwukrotnie ${ }^{19}$.

W myśl artykułu 109 ustawy, cudzoziemiec nie zostanie objęty ochroną czasowa, gdy jest podejrzany o dokonanie zbrodni przeciw pokojowi, zbrodni wojennej lub przeciw ludzkości; popełnienie zbrodni o charakterze niepolitycznym; lub dopuszczenie się czynów sprzecznych z celami i zasadami wymienionymi w Karcie Narodów Zjednoczonych. Ochrony czasowej nie otrzyma także osoba, której wjazd lub pobyt na terytorium RP może stanowić zagrożenie dla bezpieczeństwa państwa oraz osoba skazana prawomocnym wyrokiem za zbrodnię, której charakter wskazuje, że obecność tej osoby na terytorium Polski może stanowić zagrożenie dla obywateli $\mathrm{RP}^{20}$.

\section{Rozwiązania instytucjonalne}

Tworząc podstawy polskiej polityki azylowej niezbędne stało się ustanowienie instytucji zajmujących się postępowaniem statusowym, a także

18 Decyzja podejmowana jest w oparciu o przyjmowaną przez Radę listę państw uznanych za bezpieczne. Działanie takie jest niebezpieczne, gdyż sytuacja polityczna w państwie uznanym za bezpieczne może się nagle zmienić. Ewentualna weryfikacja listy nastąpi później, zaś do chwili sporządzenia nowej listy cudzoziemcy będą narażeni na niebezpieczeństwo i odsyłani do państw nie będących bezpiecznymi.

19 Artykuł 106.3 Ustawy z dnia 13 czerwca 2003 roku o udzielaniu cudzoziemcom ochrony na terytorium Rzeczypospolitej Polskiej, op. cit.

20 Artykuł 109.2. i 3. Ustawy z dnia 13 czerwca 2003 roku o udzielaniu cudzoziemcom ochrony na terytorium Rzeczypospolitej Polskiej, op. cit. 
udzielaniem ochrony osobom poszukującym w Polsce schronienia. W marcu 1990 roku Prezydium Rządu powołało Międzyresortowy Zespół do Spraw Pomocy Uchodźcom. W jego skład weszli przedstawiciele Ministerstwa Pracy i Polityki Socjalnej, Spraw Zagranicznych, Spraw Wewnętrznych oraz Obrony Narodowej ${ }^{21}$. Powołanie zespołu wiązało się bezpośrednio z przybyciem do Polski 300-osobowej grupy cudzoziemców z Afryki i Środkowego Wschodu. Osoby te zostały odesłane ze Szwecji, gdyż w poszukiwaniu schronienia przedostały się tam nielegalnie z terytorium Polski. W grudniu 1990 roku, przewidując pojawienie się uchodźców ze Wschodu, w miejsce Międzyresortowego Zespołu powołano Biuro Pełnomocnika Ministra Spraw Wewnętrznych do Spraw Uchodźców. Do zadań Biura należało opiniowanie wniosków o przyznanie statusu uchodźcy, opieka nad osobami występującymi z wnioskiem oraz prowadzenie postępowania w sprawach. W wyniku rozszerzenia działalności, 2 lutego 1993 roku Biuro Pełnomocnika przekształcone zostało w Biuro do Spraw Migracji i Uchodźstwa ${ }^{22}$, działające w ramach Ministerstwa Spraw Wewnętrznych. Biuro było odpowiedzialne za przyjmowanie i rozpatrywanie wniosków o nadanie statusu uchodźcy, przyznawanie statusu i udzielanie azylu, wydawanie dokumentów podróży, kart stałego pobytu, a także za sprawowanie nadzoru nad wykonywaniem zadań przez terenowe organy administracji rządowej i samorząd terytorialny. Reforma centrum administracyjnego spowodowała, iż w miejsce Biura powołano Departament Ministerstwa Spraw Wewnętrznych i Administracji do Spraw Migracji i Uchodźstwa. Do zadań Departamentu (oprócz zadań przejętych od Biura do Spraw Migracji i Uchodźstwa) zaliczono organizowanie dobrowolnej repatriacji i przesiedleń uchodźców oraz nadzór nad centralnym ośrodkiem recepcyjnym w Dębaku.

Zgodnie ze zmianami wprowadzonymi w kwietniu 2001 roku na mocy nowelizacji ustawy o cudzoziemcach oraz zgodnie z zapisami ustawy z 13 czerwca 2003 roku, postępowanie w sprawach o nadanie statusu uchodźcy, ochrony czasowej czy pobytu tolerowanego, prowadzone było przez Urząd do spraw Repatriacji i Cudzoziemców - URIC. Urząd utworzony został jako centralny organ administracji rządowej, podlegający nadzorowi Ministerstwa Spraw Wewnętrznych i Administracji. Na czele

21 M. Szonert, Działalność Departamentu do Spraw Migracji i Uchodźstwa MSWiA na rzecz uchodźców, materiał opracowany na potrzeby Ministerstwa Pracy i Polityki Socjalnej w związku z przekazaniem zakresu działania na rzecz integracji uchodźców, Warszawa 1998, s. 1.

22 Ibidem, s. 2. 
URIC stał Prezes, który oprócz decyzji w sprawie przyznania statusu uchodźcy, azylu terytorialnego, pobytu tolerowanego i ochrony czasowej, wydawał również decyzje w sprawach wjazdu na terytorium RP, ich pobytu i wyjazdu „obywateli państw członkowskich Unii Europejskiej, państw Europejskiego Obszaru Gospodarczego, nie należących do Unii Europejskiej” lub państw, które nie są stronami umowy o EOG, lecz mogą korzystać ze swobody przemieszczania się na podstawie umów zawartych ze Wspólnotą i jej państwami członkowskimi. Do zadań Prezesa URIC należało także analizowanie sytuacji migracyjnej, gromadzenie informacji na temat zjawiska migracji dobrowolnej i niedobrowolnej oraz prowadzenie międzynarodowej współpracy.

W związku z nowelizacją ustawy z 13 czerwca 2003 roku, od 20 lipca 2007 roku zadania Prezesa URIC przejął Szef Urzędu do Spraw Cudzoziemców. Jest to organ właściwy w sprawach dotyczących udzielania cudzoziemcom ochrony na terytorium RP, wspomagany przez Departament Postępowań Uchodźczych oraz Biuro Organizacji Ośrodków dla Cudzoziemców ubiegających się o Nadanie Statusu Uchodźcy lub Azylu ${ }^{23}$. Departament Postępowań Uchodźczych jest odpowiedzialny za prowadzenie spraw dotyczących nadania i cofnięcia statusu uchodźcy, azylu, ochrony uzupełniającej oraz udzielaniem i cofaniem zgody na pobyt tolerowany oraz ochronę czasową. Dla realizacji powyższych zadań, w ramach Departamentu powołano trzy wydziały postępowań uchodźczych, Wydział Postępowań Dublińskich oraz Wydział Informacji o Krajach Pochodzenia. Działalność dwóch ostatnich jednostek związana jest ściśle z procedurami obowiązującymi w ramach Wspólnego Europejskiego Systemu Azylowego, w szczególności z rozporządzeniem Dublin II z 18 lutego 2003 roku oraz postanowieniami w sprawie państw bezpiecznych. Biuro Organizacji Ośrodków dla Cudzoziemców ubiegających się o Nadanie Statusu Uchodźcy lub Azylu świadczy pomoc cudzoziemcom ubiegającym się o status uchodźcy lub azyl oraz osobom korzystającym z ochrony czasowej. Biuro jest również zobowiązane do logistycznej obsługi ośrodków dla uchodźców.

Zasady postępowania przy identyfikacji uchodźców, przyjęte w 1977 roku przez Komitet Wykonawczy UNHCR wskazują, że osoby ubiegające się o status uchodźcy powinny mieć prawo odwołania się od decyzji do or-

23 Oprócz spraw uchodźczych, Urząd do spraw Cudzoziemców pełni również rolę Centralnego Organu Wizowego, zgodnie z wymogami Konwencji Wykonawczej do Porozumienia z Schengen, przyjętej w 1990 roku. 
ganu administracyjnego drugiej instancji. Zabiegi UNHCR oraz organizacji pozarządowych skłoniły polskiego ustawodawcę do powołania Rady do Spraw Uchodźców, utworzonej na mocy ustawy o cudzoziemcach z 25 czerwca 1997 roku. Pozycję Rady umocniły postanowienia ustaw z czerwca 2003 roku o cudzoziemcach oraz o udzielaniu cudzoziemcom schronienia na terytorium RP. Celem było zapewnienie osobom ubiegającym się o ochronę prawną w Polsce możliwości zaskarżania w trybie administracyjnym decyzji Prezesa URIC, a obecnie decyzji Szefa Urzędu do spraw Cudzoziemców. Do podstawowych zadań Rady należy więc rozpatrywanie odwołań od postanowień wydanych przez Szefa Urzędu do spraw Cudzoziemców w sprawach o nadanie lub pozbawienie statusu uchodźcy, a także rozpatrywanie spraw dotyczących „wznowienia postępowania, uchylenia, zmiany lub stwierdzenia nieważności wydanych decyzji lub postanowień" ${ }^{24}$. Ponadto Rada dokonuje analizy orzecznictwa, gromadzi informacje o państwach pochodzenia cudzoziemców, współpracuje z organami i instytucjami krajowymi i zagranicznymi zajmującymi się problematyką uchodźstwa i migracji, prowadzi również rejestr złożonych zażaleń, odwołań i decyzji wydanych przez Radę.

Rada składa się z dwunastu osób powoływanych przez Prezesa Rady Ministrów na pięcioletnią kadencję. Członkowie Rady powoływani są spośród osób posiadających wiedzę teoretyczną lub praktyczną znajomość problematyki uchodźstwa. Co najmniej połowa członków Rady musi posiadać wyższe wykształcenie prawnicze. Wpływ na obsadzanie stanowisk w Radzie mają, oprócz premiera, Minister Spraw Zagranicznych i Minister Sprawiedliwości. Każdy z ministrów wskazuje ośmiu kandydatów, z których premier wybiera po czterech, powołując ich na członków Rady do Spraw Uchodźców.

Jako organ odwoławczy Rada powinna być bezstronna i niezależna od ewentualnych nacisków ze strony innych organów państwa. Próbą zagwarantowania niezależności Rady jest tryb odwoływania jej członków. Artykuł 89t.1 ustawy o udzielaniu cudzoziemcom ochrony przewiduje, że odwołanie członka Rady może nastąpić jedynie w przypadku: złożenia przez niego rezygnacji; choroby trwale uniemożliwiającej sprawowanie funkcji; skazania prawomocnym wyrokiem za przestępstwo popełnione z winy umyślnej, ścigane z oskarżenia publicznego lub za przestępstwo skarbowe; lub zaistnienia innych okoliczności uniemożliwiających spra-

24 Artykuł 89p.3 Ustawy z dnia 13 czerwca 2003 roku o udzielaniu cudzoziemcom ochrony na terytorium Rzeczypospolitej Polskiej, op. cit. 
wowanie funkcji lub wywiązanie się z obowiązków. Uznać należy więc, że formalnie Rada do Spraw Uchodźców nie jest organem administracji rządowej, gdyż nie podlega żadnemu organowi szczebla rządowego ${ }^{25}$.

Rada orzeka w trzyosobowych składach jedynie w oparciu o przepisy prawa. Orzeczenia zapadają większością głosów, członek składu orzekającego nie ma możliwości wstrzymania się od głosu. Podobnie jak w postępowaniu w I instancji, przed wydaniem decyzji Rada zwraca się do Szefa Agencji Bezpieczeństwa Wewnętrznego o przekazanie informacji czy wobec cudzoziemca zachodzą okoliczności wskazane w artykule 1F Konwencji Genewskiej z 1951 roku i czy pobyt tej osoby na terytorium RP stanowi zagrożenie dla obronności lub bezpieczeństwa państwa. Czyni to jednak wówczas, gdy z akt sprawy wynika, że Szef Urzędu do spraw Cudzoziemców z takim pytaniem się nie zwrócił.

Obowiązujące obecnie rozwiązania instytucjonalne przyznają cudzoziemcowi ubiegającemu się o status uchodźcy, azyl terytorialny, ochronę czasową lub pobyt tolerowany prawo skargi na decyzję podjętą w postępowaniu administracyjnym. Skargę wnosi się osobiście lub za pośrednictwem adwokata $\mathrm{w}$ terminie 30 dni od dnia doręczenia decyzji do wojewódzkiego sądu administracyjnego, właściwego dla województwa mazowieckiego. Od decyzji wojewódzkiego sądu administracyjnego przysługuje kasacja do Naczelnego Sądu Administracyjnego ${ }^{26}$. W zakresie spraw uchodźczych NSA wypowiadał się między innymi na temat długości postępowania statusowego (wyrok z 7 marca 2000 roku), czy obowiązku przedstawienia dowodów potwierdzających ustalenia stanu faktycznego dokonane przez organ administracyjny (wyrok z 23 lutego 2000 roku). Istotne znaczenie miały orzeczenia dotyczące terminów składania wniosków o przyznanie statusu uchodźcy. Zgodnie z rozwiązaniami ustawy o cudzoziemcach z 1997 roku, wniosek o nadanie statusu uchodźcy należało złożyć przy przekraczaniu granicy RP, w ciagu 14 dni od przekroczenia granicy lub w ciagu 14 dni od uzyskania wiadomości o zaistnieniu w państwie pochodzenia okoliczności uzasadniających nadanie statusu uchodźcy. Niedotrzymanie terminów skutkowało odmową wszczęcia po-

25 J. Jagielski, Wybrane administracyjno-prawne aspekty problematyki uchodźców w Polsce, w: Ochrona uchodźców. Dziesiata rocznica przystapienia Polski do Konwencji Genewskiej, red. G. Mioduszewska, Warszawa 2002, s. 167.

26 Taka procedura obowiązuje od 1 stycznia 2004 roku w związku z wprowadzeniem dwuinstancyjnego postępowania administracyjnego. Wcześniej od decyzji podjętej w I instancji przysługiwała bezpośrednio skarga do NSA. 
stępowania $^{27} .26$ sierpnia 1999 roku NSA stwierdził, że te zapisy ustawy są niezgodne z zamierzeniem twórców Konwencji Genewskiej z 1951 roku, którzy wyraźnie wskazali warunki jakie należy spełnić, aby uzyskać ochronę, i nie wprowadzili ograniczeń czasowych w odniesieniu do składania wniosku o nadanie statusu uchodźcy. Zdaniem Sądu przepisy prawa wewnętrznego nie mogą wprowadzać dodatkowych warunków nadania statusu uchodźcy. Wyrok z sierpnia 1999 roku doprowadził dwa lata później do nowelizacji ustawy o cudzoziemcach z 1997 roku. Naczelny Sąd Administracyjny zajmował się również kwestią świadczeń przysługujących osobom ubiegających się o status uchodźcy (wyrok z 30 maja 2000 roku). Z punktu widzenia praktyki przyznawania statusu uchodźcy największe znaczenie miały jednak interpretacje terminu ,prześladowanie” dokonane przez NSA. Sąd uznał między innymi, że: uzasadniona obawa przed prześladowaniem jest odczuciem subiektywnym, ale wymaga oceny w oparciu o obiektywne okoliczności ${ }^{28}$; że naruszeniem praw człowieka, a jednocześnie przyczyną prześladowania jest zmuszanie do publicznego wyznawania religii lub zmuszanie do wynikającego z nakazów religijnych wyglądu lub zachowania (wyrok z 24 sierpnia 2000 roku); że o status uchodźcy mogą ubiegać się kobiety narażone na przemoc seksualną, gdyż przemoc na tle seksualnym jest uznawana przez międzynarodowe prawo praw człowieka i międzynarodowe prawo karne za naruszenie praw człowieka (wyrok z 8 maja 2008 roku). Sędziowie zwrócili również uwagę, że nie jest trafne stanowisko organów, zgodnie z którym wnioskodawca powinien zawsze wykazać, że w państwie pochodzenia wyczerpał dostępne środki ochrony. Uznali, że „warunek braku ochrony ze strony państwa nie może być w każdym przypadku rozumiany jako bezwzględny obowiązek wyczerpania dostępnych w kraju procedur ochronnych osobiście". Często bowiem dochodzi do sytuacji, w których osoba żywiąca uzasadnioną obawę przed prześladowaniem lub będąca ofiarą prześladowań nie ma faktycznej możliwości skorzystania $\mathrm{z}$ ochrony w państwie pochodzenia, pomimo iż formalnie ochrona taka tej osobie przysługuje.

Jak widać z powyższych rozważań, w toku kilkukrotnych zmian ustawowych, w odniesieniu do spraw dotyczących uchodźców stworzono system

27 Szerzej: A. Potyrała, Polskie rozwiqzania prawne dotyczace uchodźców a standardy europejskie, w: Polska wobec Unii Europejskiej. Wybrane zagadnienia, red. S. Wojciechowski, Poznań 2001, s. 61.

28 Por. Wyrok Naczelnego Sqdu Administracyjnego z 3 sierpnia 2000, sygn. akt V SA 150/00, ONSA 2001, z. 4, poz. 172. 
o charakterze administracyjno-sądowym. Rolę organów administracyjnych pełnią obecnie Urząd do spraw Cudzoziemców i Rada do spraw Uchodźców. Organami sądowymi, uprawnionymi do rozpatrywania spraw związanych ze statusem uchodźcy, ochroną uzupełniającą, ochroną czasową czy azylem są wojewódzki sąd administracyjny (właściwy dla województwa mazowieckiego) i Naczelny Sąd Administracyjny. Analizując instytucjonalne podstawy polskiej polityki azylowej nie sposób jednak pominąć roli Straży Granicznej, która na mocy postanowień ustawy o cudzoziemcach z 1997 roku, otrzymała uprawnienia do przyjmowania wniosków o nadanie statusu uchodźcy. Zgodnie z artykułem 28 ustawy z 2003 roku wniosek może być złożony przez cudzoziemca:

- przekraczającego granicę RP do komendanta oddziału Straży Granicznej lub komendanta granicznej placówki kontrolnej Straży Granicznej;

- nie posiadającego dokumentów uprawniających do przekroczenia granicy RP do komendanta placówki Straży Granicznej;

- przebywającego na terytorium RP do komendanta oddziału Straży Granicznej, obejmującego zasięgiem działania miasto stołeczne Warszawa;

- przebywającego w strzeżonym ośrodku lub w areszcie w celu wydalenia z Polski, lub przebywającego w areszcie śledczym lub zakładzie karnym do komendanta oddziału Straży Granicznej, obejmującego zasięgiem działania siedzibę strzeżonego ośrodka, aresztu, aresztu śledczego lub zakładu karnego ${ }^{29}$.

W tym względzie Straż Graniczna podejmuje działania w oparciu o postanowienia czterech ustaw: ustawy o Straży Granicznej z 12 października 1990 roku, ustawy o ochronie granicy państwowej, ustawy o cudzoziemcach oraz ustawy o udzielaniu cudzoziemcom ochrony na terytorium RP z 13 czerwca 2003 roku. Dążąc do realizacji zapisów tych dokumentów, w ramach struktury Komendy Głównej Straży Granicznej wyodrębniono Zarząd do spraw Cudzoziemców. Wydział I Zarządu odpowiedzialny jest za organizację wydaleń cudzoziemców oraz organizację dobrowolnych repatriacji, a także za przekazywanie osób wnioskujących o status uchodźcy do innych państw członkowskich Unii Europejskiej na mocy rozporządzenia Dublin II z 2004 roku, o którym mowa wcześniej. Wydział II Zarządu do spraw Cudzoziemców realizuje zadania wykonawcze w odniesieniu do odwołań od decyzji podjętych przez komendantów placówek

29 Por. Artykuł 28.1-4 Ustawy z dnia 13 czerwca 2003 roku o udzielaniu cudzoziemcom ochrony na terytorium Rzeczypospolitej Polskiej, op. cit. 
Straży Granicznej. Wydział III sprawuje nadzór i koordynuje działania poszczególnych jednostek organizacyjnych Straży Granicznej, zajmuje się również współpracą $\mathrm{z}$ organami administracji rządowej i pozarządowej, odpowiednimi instytucjami państw członkowskich UE, ale również z organizacjami pozarządowymi, a także z Przedstawicielstwem Urzędu Wysokiego Komisarza NZ do spraw Uchodźców.

$* * *$

Przyjęte w Polsce rozwiązania prawne dostosowane zostały do zobowiązań wynikających z treści Konwencji dotyczącej Statusu Uchodźców i Protokołu Dodatkowego, a także do wymogów stawianych przez Unię Europejską. Dynamika zmian europejskiego prawodawstwa azylowego, powodowana zróżnicowaną sytuacją migracyjną w poszczególnych państwach członkowskich, koniecznością zagwarantowania bezpieczeństwa Unii Europejskiej oraz koniecznością wypracowania jednolitego podejścia do problemów azylowych, wymusza nieustanne dostosowanie polskiego prawa do wymogów europejskich. Ważne jest jednak, aby działania polskich organów nie ograniczyły się jedynie do przyjmowania i stosowania rozwiązań europejskich, lecz aby koncentrowały się na tworzeniu tych regulacji. Szczególnie ważne jest zagwarantowanie współdziałania organów administracji państwowej w sprawach uchodźczych oraz stosowanie przyjętych w Polsce rozwiązań prawnych nie tylko zgodnie z litera, ale i duchem Konwencji Genewskiej dotyczącej statusu uchodźców i Protokołu Dodatkowego.

\section{Summary}

Polish refugee policy dates back to September 26, 1991 when the Republic of Poland ratified the Geneva Convention relating to the Status of Refugees of 1951 and the New York Additional Protocol of 1967. The adoption of provisions of both these international documents obliged Poland to amend the Law on Foreigners of March 29, 1963. The changes introduced in 1991 have not concluded the matter. Membership of the European Union resulted in the adaptation of Polish legislation to the requirements of the Common European Asylum System. Consequently, persons seeking asylum in Poland can be granted protection in the form of refugee status, temporary protection, asylum (defined as territorial asylum), subsidiary protection and tolerated residence. The dynamics of the European asylum law results from diversified migration situations in the member states, as well as from the necessity to guarantee the security of the EU and to work out a unified approach to asylum problems. All this requires further legal and institutional changes. 